\title{
Haploinsufficiency of the Mouse Atp6v1b1 Gene Leads to a Mild Acid-Base Disturbance with Implications for Kidney Stone Disease
}

\author{
Soline Bourgeois ${ }^{\mathrm{a}} \quad$ Carla Bettonia $^{\mathrm{a}} \quad$ Stéphanie Baron ${ }^{\mathrm{b}} \quad$ Carsten A. Wagner $^{\mathrm{a}}$ \\ aInstitute of Physiology, University of Zurich, Zurich, Switzerland, 'bHôpital Européen Georges Pompidou, \\ Département de Physiologie, Assistance Publique-Hôpitaux de Paris, Paris, France
}

\section{Key Words}

Distal renal tubular acidosis $•$ Heterozygosity $\bullet$ Collecting duct

\begin{abstract}
Background/Aims: Homozygous mutations or deletion of the ATP6V1B1 gene encoding for the B1 subunit of the vacuolar $\mathrm{H}^{+}$-ATPase leads to distal renal tubular acidosis in man and mice. In humans, heterozygous carriers of B1 mutations can develop incomplete dRTA

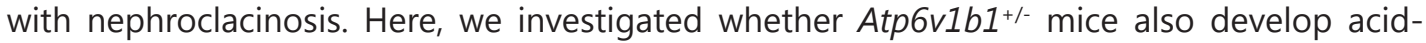

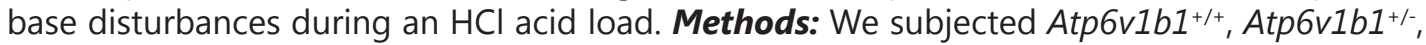

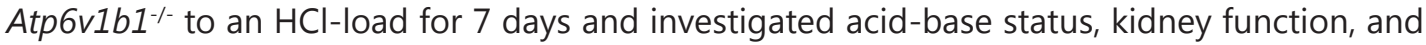
expression of renal acid-base transport proteins. Results: Atp6v1b1/- mice had more alkaline urine and low ammoniuria, whereas Atp $6 \mathrm{v} 1 b 1^{+/}$mice showed no difference in their urine parameters but higher blood chloride and lower blood $\mathrm{pCO}_{2}$ compared to controls. Subcellular localization of a4 and B2 subunits of $\mathrm{H}^{+}$-ATPase were unchanged within the 3 genotypes

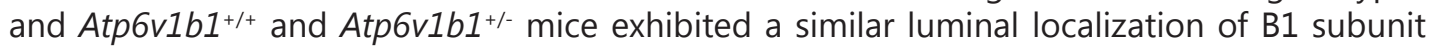
in intercalated cells. However, B1, B2 and a4 expression were decreased in renal membrane

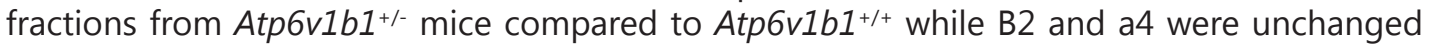
and B1 protein was reduced in Atp6v1 $b^{+-/}$kidneys. Compensatory mechanisms of B1 ablation were found only in the collecting duct with a down-regulation of pendrin in Atp6v1 b1 1 mice. Conclusions: In conclusion, 1) Atp6r $1 b 1^{+/-}$mice developed a mild incomplete dRTA. dRTA is partly compensated by respiration. 2) Compensatory mechanisms for the absence of B1 take place only in the collecting duct of Atp6v1b1-1- kidneys.

\section{Introduction}

Extracellular $\mathrm{pH}$ has to be tightly kept in the normal physiologic range of $\mathrm{pH}$ 7.36-7.44 to maintain normal organ and body function. The kidney has a major role in controlling and maintaining systemic acid-base status by three intricately linked mechanisms: the reabsorption of filtered bicarbonate, the excretion of acids in the form of ammonium 
and titratable acidity (mainly as phosphate), and the de novo generation of bicarbonate essentially during ammoniagenesis. The latter process allows the excretion of acids and the replenishing of bicarbonate used to buffer acids. The reabsorption of filtered bicarbonate is mostly achieved by the proximal tubule and to a lesser extent by the thick ascending limb and the distal convoluted tubule (for review, [1]). Under Western diet, an acid-producing diet, urine entering the connecting tubule contains only minute amounts of bicarbonate [1]. The ultimate fine-tuning of renal acid or base excretion takes place in the collecting system involving various cell types and distinct transport proteins. In the collecting system, acidsecretory type-A intercalated cells secrete protons via an apically located V-type $\mathrm{H}^{+}$-ATPase and generate new bicarbonate released by basolateral chloride/bicarbonate exchangers including the AE1 anion exchanger [2]. The V-type $\mathrm{H}^{+}$-ATPase is a multimeric protein complex with at least 16 subunits differentially expressed along the nephron [3]. In the kidney, the B1 subunit, part of the cytosolic $\mathrm{V}_{1}$ domain, is mostly expressed in the various types of intercalated cells of the collecting system (review [3, 4]).

The importance of collecting duct acid-base excretion to overall systemic acid-base balance is highlighted by several rare inherited disorders affecting collecting duct acid-base transport proteins causing distal renal tubular acidosis (dRTA) (for review [5, 6]_ENREF_2). In man, mutations in the ATP6V1B1 gene lead to dRTA and sensorineural hearing loss and the disease is considered to be inherited in an autosomal recessive manner [7-9]. However, it has been shown recently in a kindred with a truncation mutation of ATP6V1B1, $(p$. Phe468fs X487), that heterozygosity could lead to a mild incomplete dRTA with more alkaline urine and nephrocalcinosis [10]. In a follow-up study the authors investigated the role of the $p . E 161 K$ variant in a cohort of stone formers and could show that heretozygous carriers exhibited a mild urinary acidification deficit with an increased prevalence of calciumphosphate kidney stones [11]. In mouse, total ablation of the Atp6v1b1 gene causes dRTA with a decrease in ammonium excretion and more alkaline urine $\mathrm{pH}$ [7]. However, the impact of haploinsufficiency on renal acid handling has never been investigated so far. Thus our aim was to determine whether Atp $6 v 1 b 1$ heterozygote mice also exhibit some features of dRTA in order to gain new insights whether haploinsufficiency may help explaining the occurrence of incomplete dRTA in carriers with monoallelic ATP6V1B1 mutations.

\section{Materials and Methods}

\section{Animals}

Generation and breeding of Atp $6 \mathrm{v} 1 \mathrm{~b} 1 \%$ mice has been previously described [19]. Experimental mice were generated by mating Atp $6 v 1 b 1^{+/-}$mice. All experiments were performed with 6 to 7 months old littermate mice according to Swiss Animal Welfare laws and approved by the local veterinary authority (Veterinäramt Zürich).

\section{In vivo experiments}

All experiments were performed using age- and sex-matched Atp6v1b1 wildtype $\left(A t p 6 v 1 b 1^{+/+}\right)$,

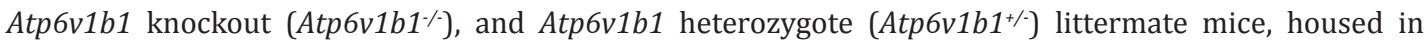
metabolic cages (Techniplast, Switzerland). Mice were given deionized water ad libitum and were fed with a standard powdered laboratory chow (Kliba, Augst, Switzerland) mixed with deionized water (a 50:75 mixture (w/V)). Mice were allowed to adapt to metabolic cages for 3 days and a first retro-orbital blood sample was taken for blood gas analysis under baseline. Then two $24 \mathrm{hrs}$ urine samples were collected under light mineral oil in the urine collector to determine daily urinary parameters. Mice were then allowed to recover for 2 weeks in normal cages. Metabolic acidosis was induced by diet $(0.2 \mathrm{M} \mathrm{HCl}$ in standard powdered food) for 7 days. Food, water intake, and urine excretion was monitored following the same procedures as under baseline conditions. Urine collections were performed on the first and second day of acid-loading, and then on the sixth and seventh day. Retro-orbital blood samples were taken on the second and seventh day of the $\mathrm{HCl}$ diet. 


\section{Cellular Physiology Cell Physiol Biochem 2018;47:1095-1107 \begin{tabular}{l|l} 
and Biochemistry Published online: May 30, 2018 & $\begin{array}{l}\text { D) 2018 The Author(s). Published by S. Karger AG, Basel } \\
\text { www.karger.com/cpb }\end{array}$ \\
\hline
\end{tabular}}

Bourgeois et al.: Phenotype of Atp6v1b1 Haploinsufficiency in Mice

\section{Analytic procedures}

Blood $\mathrm{pH}, \mathrm{pCO}_{2}$, and electrolytes were measured with a $\mathrm{pH} /$ blood-gas analyzer (ABL 77 Radiometer). Urinary $\mathrm{Na}^{+}, \mathrm{Cl}^{-}, \mathrm{NH}_{4}{ }^{+}, \mathrm{K}^{+}, \mathrm{PO}_{4}{ }^{2+}, \mathrm{Ca}^{2+}$, creatinine and urea concentrations were determined on an UniCel DxC 800 Synchron Clinical Systems (Beckman Coulter). Urine titratable acidity was measured in accordance with Jorgensen and Siggaard-Andersen [31, 32]. Briefly, $\mathrm{CO}_{2}$ was eliminated by hydrochloric acid addition. Then, titratable acidity was measured by sodium hydroxyde $(1 \mathrm{~N})$ titration to $\mathrm{pH} 7.40$ with DL 55 Mettler Toledo® titrator, ST20 Mettler ${ }^{\circledR}$ sample changer and Inlab® Semi micro pH electrode. Urinary pH was measured on fresh urine with a pHmeter. Citric acid was measured using a kit from Boehringer Mannheim/ R-Biopharm.

\section{Immunohistochemistry}

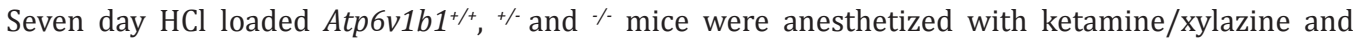
perfused through the left heart ventricle with a pre-fixative solution $(1000 \mathrm{U} / \mathrm{ml}$ Heparin, $0.2 \%$ procain- $\mathrm{HCl}$, $3.2 \% \mathrm{CaCl}_{2}$ and $0.18 \% \mathrm{NaCl}$ ) followed by the fixative (3\% Paraformaldehyde (PFA)/PBS). After incubation in PFA/PBS for one hour, kidneys were placed overnight in 32\% sucrose/PBS and subsequently embedded in OCT embedding Matrix (Cell Path, Newtown, Wales, United Kingdom) and frozen in liquid propane. Cryosections of $3 \mu \mathrm{m}$ were mounted on slides (Superfrost Plus, Thermo Scientific). Autofluorescence from free aldehydes sites was quenched by incubation of the slides in a $50 \mathrm{mM} \mathrm{NH}_{4} \mathrm{Cl} / \mathrm{PBS}$ solution during 20 min. Sections were then treated with $1 \%$ SDS/PBS during 5 min, washed with PBS, and blocked with $1 \%$ bovine serum albumin/PBS. After blocking, sections were incubated with primary antibodies (guinea pig anti-AE1 1:500 [33], rabbit anti-a4 $\mathrm{H}^{+}$-ATPase 1:500 [34], rabbit anti-B1 $\mathrm{H}^{+}$-ATPase [34], rabbit anti-B2 $\mathrm{H}^{+}$ATPase 1:500 [35], and goat anti AQP-2 (Santa Cruz Biotechnology), 1:1000) diluted in PBS for incubation over night at $4^{\circ} \mathrm{C}$. Then, samples were washed 3 times with PBS/NaCl (18g NaCl/PBS), and incubated with the secondary antibodies (donkey anti-rabbit 594, donkey anti-goat 488 and donkey anti-guinea pig 647 (Molecular Probes) at 1:1000 and DAPI, 1:400) during 2 hours at room temperature. After three consecutive washing steps with PBS coverslips were mounted with Glycergel (DakoCytomation, Baar, Switzerland). Fluorescence was detected with a Leica fluorescence microscope.

\section{Immunoblotting}

Brush border membranes and total membrane fractions were obtained from 7-day HCl loaded Atp $6 v 1 b 1^{+/+},+$and $\%$ mouse kidneys. For total membrane preparations, frozen kidneys were homogenized in an ice-cold K-HEPES buffer (200 mM mannitol, 80 mM HEPES, 41 mM KOH, pH 7.5) containing a protease inhibitor mix (Complete Mini, Roche Diagnostics, Germany) at a final concentration of 1 tablet in a volume of $10 \mathrm{ml}$ solution. Samples were centrifuged at $2000 \mathrm{rpm}$ for $20 \mathrm{~min}$ at $4^{\circ} \mathrm{C}$. Subsequently, the supernatant was transferred to a new tube and centrifuged at $41^{\prime} 000 \mathrm{rpm}$ for $1 \mathrm{~h}$ at $4^{\circ} \mathrm{C}$. The resultant pellet was resuspended in K-HEPES buffer containing protease inhibitors. For brush border membrane preparations, frozen kidneys were homogenized in homogenization buffer (300 mM Mannitol, 5 mM EGTA, 12 mM Tris/HCl, pH 7.1) for 2 min on ice using a Polytron homogenizer (PT 10-35, Kinematica GmbH, Lucerne). The homogenates were then diluted in water $(\mathrm{x} 1.4 \mathrm{v} / \mathrm{v})$ and $\mathrm{MgCl}_{2}$ was added at a final concentration of $12 \mathrm{mM}$. Brush border membranes were precipitated $15 \mathrm{~min}$ on ice and then centrifuged at $4500 \mathrm{rpm}$ for $15 \mathrm{~min}$ at $4^{\circ} \mathrm{C}$. The pellet was resuspended in $300 \mathrm{mM}$ Mannitol, $20 \mathrm{mM}$ HEPES-Tris pH 7.4 solution and centrifuged at $18000 \mathrm{rpm}$ for $30 \mathrm{~min}$ at $4^{\circ} \mathrm{C}$. The pellet was resuspended and kept at $80^{\circ} \mathrm{C}$. Protein concentrations were determined with the BioRad DC protein assay, based on the Lowry method (Bio-Rad, Hercules, CA, USA) [36].

Up to fourty micrograms of total membrane proteins or brush border membranes were solubilized in Laemmli loading buffer containing 10\% DTT and separated on 8 to $10 \%$ polyacrylamide gels. For immunoblotting, proteins were transferred electrophoretically to polyvinylidene fluoride membranes (Immobilon-P, Millipore Corp., Bedford, MA, USA). After blocking with $5 \%$ milk powder in Tris-buffered saline/0.1\% Tween-20 for $60 \mathrm{~min}$, blots were incubated with primary antibodies: rabbit anti-mouse Atp6v1b1 (B1) (1:5, 000) [37], rabbit anti-ATP6v1b2 (B2) (1:5, 000) [35], rabbit anti-ATP6v0a4 [34], (1:5, 000), rabbit anti- ATP6v1A 1:2, 000, rabbit anti-pendrin (1:2, 000) [29], rabbit anti-AE1 (1:2, 000) [33], rabbit anti-AQP2 $(1: 2,000)$ and rabbit anti-NKCC2 $(1: 5,000)$ (kind gift of J. Loffing, University of Zurich) [38], rabbit anti-NBCe1 $(1: 1,500)$ (Proteintech, United Kingdom), rabbit anti-NHE3 $(1: 2,000)$ (StressMarq Biosciences, Inc, Victoria, British Columbia) and mouse monoclonal anti- $\beta$-actin antibody (Sigma, St. Louis, MO; $1: 20,000$ ) overnight at $4^{\circ} \mathrm{C}$. After washing and blocking with $5 \%$ milk powder for 60 min, membranes were incubated for $2 \mathrm{~h}$ at room temperature with secondary goat anti-rabbit or donkey anti- 
mouse antibodies 1:5, 000 linked to alkaline phosphatase (Promega, Madison, WI, USA). The protein signal was detected with the appropriate substrate (Millipore Corp, Bedford, MA, USA) using the las-4000 image analyzer system (Fujifilm Life Science USA). All images were analyzed using Advanced Image Data Analyzer AIDA (Raytest, Straubenhardt, Germany) to calculate the protein of interest/ $\beta$-actin ratio.

\section{Statistics}

Data are shown as means \pm SEM. Comparisons between experimental conditions were performed using non parametric ANOVA (Kruskal-Wallis test) or one-way ANOVA of variance with Bonferroni test. P values of $\leq 0.05$ were chosen to indicate statistical significance.

\section{Results}

Atp6v1b1 heterozygous mice exhibit no overt dRTA but develop an intermediate phenotype compared to knockout and wildtype animals

We first assessed acid-base status under basal conditions and during an acid load in Atp6v1b1 wildtype, heterozygote or homozygote littermates. Throughout the study, food intake was similar in all three genotypes. At baseline, no difference in acid-base and electrolyte levels was observed (Tables 1 and 2). The effects of both acute (2 days) and chronic ( 7 days) $\mathrm{HCl}$ loading were tested (Tables 1 - 3, Fig. 1 and 2).

On the second day of the $\mathrm{HCl}$ load, blood $\mathrm{pH}$ was not different between the 3 strains of mice. In contrast, blood $\mathrm{pCO}_{2}$ was drastically reduced after 2 days of $\mathrm{HCl}$-loading and despite some recovery remained significantly lower in heterozygous mice (Table 1). Blood $\mathrm{HCO}_{3}^{-}$ concentration was decreased by $\mathrm{HCl}$-loading after 2 days of treatment in all genotypes as compared with baseline (Table 1, Fig. 1C) which was paralleled by an increase in blood Cl- (Fig. 1D, Table 1). However, after 7 days of $\mathrm{HCl}$-loading, blood $\mathrm{HCO}_{3}^{-}$and $\mathrm{pH}$ were not different to baseline anymore in Atp $6 v 1 b 1^{+/+}$indicating normal adaptation of the kidney to the acid load but remained lower both in Atp6v1b1\% and Atp6v1b1\%. Moreover, blood $\mathrm{Cl}^{+}$concentration was significantly higher in Atp6v1b1\% and Atp $6 v 1 b 1^{+/-}$and than in Atp $6 v 1 b 1^{+/+}$consistent with varying degrees of metabolic acidosis in Atp $6 v 1 b 1^{+/}$and Atp $6 v 1 b 1^{\%}$ mice.

Urinary $\mathrm{pH}$ was more alkaline in Atp6v1 $1 \mathrm{~b} \%$ at baseline and remained more alkaline throughout the entire acid-loading period (Fig. 2, Tables 1-3). Similarly, urinary ammonium excretion was lower in Atp $6 v 1 \mathrm{~b} 1 \%$ mice after 2, 6 and 7 days of $\mathrm{HCl}$ acid-loading demonstrating incomplete dRTA with reduced urinary acid excretion. After 7 days of $\mathrm{HCl}$ loading, Atp $6 \mathrm{v} 1 \mathrm{~b} 1 \%$ mice had developed a nearly 3 fold lower net acid excretion compared to Atp $6 v 1 b 1^{+/+}$(Tables

Table 1. Blood values in Atp6v1b1+/+, Atp6v1b1\%, and Atp6v1b1\% littermate mice under normal diet and during an acid load. Values are mean \pm SEM, ${ }^{*}$ p $<0.05$ vs baseline period in same genotype, ${ }^{*} \mathrm{p}<0.05$ vs Atp6v1b1 $1^{+/+}$mice

\begin{tabular}{|c|c|c|c|c|c|c|c|c|c|}
\hline & \multicolumn{3}{|c|}{ Basal status } & \multicolumn{3}{|c|}{2 days $\mathrm{HCl}$} & \multicolumn{3}{|c|}{7 days $\mathrm{HCl}$} \\
\hline & Atp6v1b1+/+ & Atp6v1b1+/ & Atp6v1b1\% & Atp6v1b1+/+ & Atp6v1b1+/- & Atp $6 \mathrm{v} 1 \mathrm{~b} 1 \%$ & Atp6v1b1+/+ & Atp6v1b1+/- & Atp6v1b1\% \\
\hline & $N=5$ & $\mathrm{~N}=9$ & $\mathrm{~N}=8$ & $\mathrm{~N}=5$ & $N=9$ & $N=9$ & $N=6$ & $N=9$ & $N=9$ \\
\hline $\mathrm{pH}$ & $7.24 \pm 0.06$ & $7.34 \pm 0.01$ & $7.26 \pm 0.04$ & $7.15 \pm 0.05$ & $7.16 \pm 0.05^{*}$ & $7.21 \pm 0.02$ & $7.23 \pm 0.02$ & $7.19 \pm 0.03^{*}$ & $6.99 \pm 0.12^{*}$ \\
\hline $\mathrm{pCO}_{2}(\mathrm{mmHg})$ & $41.1 \pm 1.9$ & $39.9 \pm 1.4$ & $40.7 \pm 0.9$ & $34.6 \pm 0.8^{*}$ & $33.0 \pm 1.1^{*}$ & $34.2 \pm 1.1^{*}$ & $46.1 \pm 1.3$ & $40.6 \pm 0.86^{\#}$ & $43.7 \pm 2.7$ \\
\hline $\mathrm{HCO}_{3}(\mathrm{mM})$ & $20.0 \pm 1.6$ & $21.2 \pm 0.8$ & $18.8 \pm 1.2$ & $12.1 \pm 1.5^{*}$ & $12.0 \pm 1.3^{*}$ & $13.4 \pm 1.0^{*}$ & $18.7 \pm 0.8$ & $15.5 \pm 1.20^{*}$ & $12.3 \pm 2.2^{* \#}$ \\
\hline $\mathrm{pO}_{2}$ & $58.5 \pm 3.0$ & $52.7 \pm 2.8$ & $57.0 \pm 1.8$ & $68.8 \pm 2.2^{*}$ & $66.6 \pm 2.8^{*}$ & $64.3 \pm 2.4^{*}$ & $54.2 \pm 2.1$ & $65.9 \pm 4.58$ & $88.9 \pm 10.8^{* \#}$ \\
\hline $\mathrm{Na}(\mathrm{mM})$ & $148.2 \pm 0.6$ & $146.8 \pm 0.8$ & $147.7 \pm 0.3$ & $149.8 \pm 0,3$ & $149.9 \pm 1.0$ & $149.3 \pm 0.5$ & $151.8 \pm 0.4$ & $153.0 \pm 0.7^{*}$ & $152.2 \pm 1.3^{*}$ \\
\hline $\mathrm{Cl}(\mathrm{mM})$ & $115.0 \pm 0.6$ & $112.1 \pm 1.4$ & $115.2 \pm 0.7$ & $126.5 \pm 1.6^{*}$ & $127.3 \pm 1.5^{*}$ & $122.9 \pm 1.2^{*}$ & $118.0 \pm 0.7$ & $124.1 \pm 1.5^{* \#}$ & $130.9 \pm 4.2^{* \#}$ \\
\hline $\mathrm{Ca}(\mathrm{mM})$ & $1.25 \pm 0.01$ & $1.21 \pm 0.01$ & $1.24 \pm 0.01$ & $1.30 \pm 0.01^{*}$ & $1.34 \pm 0.03^{*}$ & $1.35 \pm 0.02 *$ & $1.31 \pm 0.01^{*}$ & $1.31 \pm 0.01^{*}$ & $1.58 \pm 0.14^{*}$ \\
\hline Urea $(\mathrm{mM})$ & ND & ND & ND & ND & ND & ND & $9.13 \pm 0.71$ & $8.5 \pm 0.8$ & $7.5 \pm 0.6$ \\
\hline Hematocrit (\%) & $44.8 \pm 0.5$ & $44.8 \pm 0.7$ & $42.5 \pm 1.6$ & $45.5 \pm 0.7$ & $44.6 \pm 1.0$ & $45.2 \pm 1.0$ & $47.4 \pm 0.8^{*}$ & $45.9 \pm 1.3$ & $49.5 \pm 1.2^{*}$ \\
\hline $\mathrm{Na}-\mathrm{Cl}(\mathrm{mM})$ & $33.2 \pm 0.7$ & $34.7 \pm 1.0$ & $32.4 \pm 0.6$ & $23.3 \pm 1.3^{*}$ & $22.6 \pm 1.8^{*}$ & $26.4 \pm 1.1^{*}$ & $33.7 \pm 0.8$ & $28.9 \pm 1.2^{*}$ & $21.3 \pm 4.5$ *\# \\
\hline
\end{tabular}




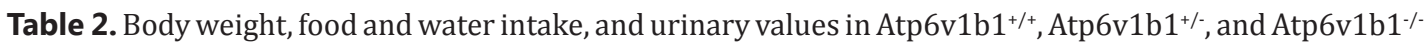
littermate mice littermates during 2 and 6 days of $\mathrm{HCl}$ loading reported to creatinine excretion. TA titratable acid; Values are mean \pm SEM. ${ }^{*} \mathrm{p}<0.05$ vs baseline period in same genotype, ${ }^{*} \mathrm{p}<0.05 \mathrm{vs}$ Atp6v1b1 ${ }^{+/+}$mice

\begin{tabular}{|c|c|c|c|c|c|c|}
\hline & \multicolumn{3}{|c|}{2 days $\mathrm{HCl}$} & \multicolumn{3}{|c|}{6 days $\mathrm{HCl}$} \\
\hline & $\begin{array}{l}\text { Atp6v1 b1 } 1^{+/} \\
\text {(N=15 to } 17)\end{array}$ & $\begin{array}{l}\text { Atp6v1b1+/- } \\
\text { (N=15 to 23) }\end{array}$ & $\begin{array}{c}\text { Atp6v1 b1 } \% \\
\text { (N=16 to } 17)\end{array}$ & $\begin{array}{l}\text { Atp6v1b1+/+ } \\
\text { (N=7 to 17) }\end{array}$ & $\begin{array}{l}\text { Atp6v1b1+/- } \\
\text { (N=11 to } 23)\end{array}$ & $\begin{array}{l}\text { Atp6v1b1\% } \\
\text { (N=9 to } 17 \text { ) }\end{array}$ \\
\hline \multicolumn{7}{|l|}{ Metabolic values } \\
\hline Weight (g) & $28.7 \pm 1.3^{*}$ & $28.6 \pm 1.0^{*}$ & $27.9 \pm 1.4^{*}$ & $28.4 \pm 0.8^{*}$ & $28.1 \pm 0.7^{*}$ & $24.0 \pm 0.9^{*} \#$ \\
\hline Food intake (g/24hrs/body weight) & $0.17 \pm 0.01$ & $0.20 \pm 0.02$ & 0.120 .02 & $0.20 \pm 0.02$ & $0.23 \pm 0.01$ & $0.22 \pm 0.03$ \\
\hline Water intake (ml/24h) & $4.16 \pm 1.16$ & $3.45 \pm 0.58$ & $4.20 \pm 0.64$ & $5.73 \pm 1.75$ & $4.22 \pm 0.55$ & $6.26 \pm 1.15$ \\
\hline \multicolumn{7}{|l|}{ Urine values } \\
\hline Volume (ml/24 h) & $298 \pm 0.37$ & $3.01 \pm 0.35$ & $2 . .54 \pm 0.33$ & $4.70 \pm 1.04$ & $4.45 \pm 0.46$ & $3.59 \pm 0.55$ \\
\hline Creatinine $(\mathrm{mM})$ & $3.96 \pm 0.33$ & $3.85 \pm 0.64$ & $3.45 \pm 0.37$ & $2.61 \pm 0.22$ & $1.98 \pm 0.27$ & $2.59 \pm 0.85$ \\
\hline Urinary pH & $5.70 \pm 0.07^{*}$ & $5.62 \pm 0.06^{*}$ & $6.11 \pm 0.08^{* \#}$ & $5.89 \pm 0.16^{*}$ & $5.74 \pm 0.04 *$ & $6.37 \pm 0.07^{* \#}$ \\
\hline $\mathrm{NH}_{4} /$ Crea $(\mathrm{mEq} / \mathrm{mmol})$ & $107.7 \pm 14.6^{*}$ & $129.2 \pm 15.6^{*}$ & $59.1 \pm 4.8^{* \#}$ & $236.9 \pm 19.0^{*}$ & $194.6 \pm 18.6^{*}$ & $113.9 \pm 6.5^{\text {*\# }}$ \\
\hline $\mathrm{Pi} /$ Crea $(\mathrm{mEq} / \mathrm{mmol})$ & $4.6 \pm 0.3$ & $4.7 \pm 0.2$ & $5.4 \pm 0.4$ & $\mathrm{ND}$ & ND & ND \\
\hline Citric acid/Crea $(\mathrm{mEq} / \mathrm{mmol})$ & $0.043 \pm 0.02$ & $0.07 \pm 0.01$ & $0.10 \pm 0.02$ & ND & ND & ND \\
\hline $\mathrm{Ca} / \mathrm{Crea}(\mathrm{mEq} / \mathrm{mmol})$ & $4.03 \pm 0.63^{*}$ & $4.00 \pm 0.52^{*}$ & $2.43 \pm 0.36^{* \# \#}$ & ND & ND & ND \\
\hline Urea/Crea (mg/mmol) & $321.1 \pm 11.8$ & $335.2 \pm 23.6$ & $283.2 \pm 11.3$ & ND & ND & ND \\
\hline $\mathrm{Na} / \mathrm{Crea}(\mathrm{mEq} / \mathrm{mmol})$ & $15.7 \pm 2.1$ & $17.3 \pm 2.3$ & $14.2 \pm 3.5$ & ND & ND & ND \\
\hline $\mathrm{Cl} /$ Crea $(\mathrm{mEq} / \mathrm{mmol})$ & $116.8 \pm 11.7^{*}$ & $131.4 \pm 20.2^{*}$ & $63.4 \pm 16.6$ & ND & ND & ND \\
\hline $\mathrm{K} /$ Crea $(\mathrm{mEq} / \mathrm{mmol})$ & $45.6 \pm 4.1$ & $47.1 \pm 4.8$ & $34.3 \pm 5.6$ & ND & ND & ND \\
\hline
\end{tabular}

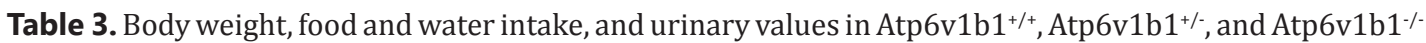
littermate mice at baseline and after 7 days of $\mathrm{HCl}$ load reported to creatinine excretion, TA titratable acid; Values are mean \pm SEM. ${ }^{*} \mathrm{p}<0.05$ vs baseline period in same genotype, ${ }^{*} \mathrm{p}<0.05$ vs Atp $6 \mathrm{v} 1 \mathrm{~b} 1^{+/+}$mice

\begin{tabular}{|c|c|c|c|c|c|c|}
\hline & $\begin{array}{l}\text { Atp6v1b1+/+ } \\
\text { (N=11 to } 17)\end{array}$ & $\begin{array}{l}\text { Basal status } \\
\text { Atp6v1b1+/- } \\
(\mathrm{N}=11 \text { to } 23)\end{array}$ & $\begin{array}{l}\text { Atp6v1b1\% } \\
\text { (N=5 to } 17)\end{array}$ & $\begin{array}{l}\text { Atp6v1b1+/+ } \\
\text { (N=7 to } 17)\end{array}$ & $\begin{array}{c}7 \text { days } \mathrm{HCl} \\
\text { Atp6v1b1+/- } \\
(\mathrm{N}=11 \text { to } 23)\end{array}$ & $\begin{array}{l}\text { Atp6v1b1\% } \\
\text { (N=7 to } 17)\end{array}$ \\
\hline \multicolumn{7}{|l|}{ Metabolic values } \\
\hline Weight (g) & $31.6 \pm 1.3$ & $30.9 \pm 0.9$ & $30.5 \pm 1.4$ & $27.5 \pm 0.9 *$ & $27.2 \pm 0.7^{*}$ & $23.9 \pm 0.9^{* \#}$ \\
\hline Food intake (g/24h/body weight) & $0.21 \pm 0.02$ & $0.26 \pm 0.02$ & $0.27 \pm 0.02$ & $0.24 \pm 0.02$ & $0.25 \pm 0.02$ & $0.22 \pm 0.04$ \\
\hline Water intake $(\mathrm{ml} / 24 \mathrm{~h})$ & $1.71 \pm 0.19$ & $1.53 \pm 0.17$ & $1.34 \pm 0.16$ & $6.20 \pm 1.75^{*}$ & $4.14 \pm 0.56^{*}$ & $4.19 \pm 0.81^{*}$ \\
\hline \multicolumn{7}{|l|}{ Urine values } \\
\hline Volume (ml/24h) & $1.90 \pm 0.22$ & $1.89 \pm 0.17$ & $1.95 \pm 0.20$ & $3.95 \pm 0.77$ & $3.96 \pm 0.46$ & 0.44 \\
\hline Creatinine (mM) & $3.45 \pm 0.37$ & $2.94 \pm 0.31$ & $3.23 \pm 0.45$ & $3.31 \pm 0.44$ & $2.28 \pm 0.33$ & $3.48 \pm 1.01$ \\
\hline Urinary $\mathrm{pH}$ & $6.13 \pm 0.06$ & $6.18 \pm 0.06$ & $6.52 \pm 0.08^{\#}$ & $5.85 \pm 0.20^{*}$ & $5.72 \pm 0.05^{*}$ & $6.34 \pm 0.09^{* \#}$ \\
\hline $\mathrm{NH}_{4} /$ Crea $(\mathrm{mEq} / \mathrm{mmol})$ & $12.8 \pm 2.3$ & $14.6 \pm 2.3$ & $10.4 \pm 1.1$ & $143.6 \pm 18.2^{*}$ & $138.7 \pm 10.15^{*}$ & $89.9 \pm 8.6^{* \#}$ \\
\hline $\mathrm{TA} / \mathrm{Crea}(\mathrm{mEq} / \mathrm{mmol})$ & ND & ND & ND & $7.6 \pm 2.1$ & $11.2 \pm 1.9$ & $5.2 \pm 1.9^{\#}$ \\
\hline $\mathrm{Pi} /$ Crea $(\mathrm{mEq} / \mathrm{mmol})$ & $6.7 \pm 0.5$ & $7.0 \pm 0.5$ & $6.31 \pm 030$ & $5.6 \pm 0.4^{*}$ & $5.1 \pm 0.3^{*}$ & $4.4 \pm 0.5^{*}$ \\
\hline Citric acid/Crea $(\mathrm{mEq} / \mathrm{m}$ & $0.25 \pm 0.11$ & $0.38 \pm 0.17$ & $0.27 \pm 0.06$ & $0.075 \pm 0.02$ & $0.10 \pm 0.02$ & $0.09 \pm 0.02$ \\
\hline Net Acid/Crea (mEq/mmol) & ND & ND & ND & $151.3 \pm 18.6$ & $149.9 \pm 9.8$ & $95.1 \pm 10.1^{\#}$ \\
\hline $\mathrm{Ca} / \mathrm{Crea}(\mathrm{mEq} / \mathrm{mmol})$ & $0.35 \pm 0.07$ & $0.43 \pm 0.09$ & $0.23 \pm 0.03$ & $4.85 \pm 0.78$ & $3.89 \pm 0.57$ & $4.80 \pm 0.86$ \\
\hline Urea/Crea (mEq/mmol) & $285.8 \pm 23.0$ & $318.3 \pm 20.1$ & $361.2 \pm 15.0$ & $398.3 \pm 18.8$ & $391.5 \pm 18.5$ & $437.8 \pm 38.5$ \\
\hline $\mathrm{Na} / \mathrm{Crea}(\mathrm{mEq} / \mathrm{mmol})$ & $13.5 \pm 1.7$ & $14.9 \pm 1.5$ & $17.6 \pm 1.7$ & $25.7 \pm 3.9$ & $29.9 \pm 4.2$ & $22.0 \pm 6.7$ \\
\hline $\mathrm{Cl} / \mathrm{Crea}(\mathrm{mEq} / \mathrm{mmol})$ & $29.3 \pm 3.2$ & $34.6 \pm 2.6$ & $34.4 \pm 3.5$ & $172.0 \pm 28.6^{*}$ & $201.6 \pm 23.7^{*}$ & $115.6 \pm 47.8^{*}$ \\
\hline $\mathrm{K} /$ Crea $(\mathrm{mEq} / \mathrm{mmol})$ & $46.1 \pm 7.6$ & $59.7 \pm 4.3$ & $58.8 \pm 5.3$ & $64.3 \pm 7.9$ & $72.4 \pm 6.4$ & $47.2 \pm 15.0$ \\
\hline
\end{tabular}

2 - 3 and Fig. 2).Atp6v1b1+/- mice exhibited an intermediate phenotype between Atp6v1b1/++ and Atp6v1 $11^{\%}$ with reduced urinary ammonium and net acid excretion (Tables 2 - 3 and Fig. 2) which however did not reach statistical significance when compared to Atp $6 v 1 \mathrm{~b} 1^{+/+}$. Patients with biallelic ATP6V1B1 mutations frequently develop nephrocalcinosis [9, 11, 12] and nephrocalcinosis has been also reported in some patients with only monoallelic ATP6V1B1 mutations $[10,11]$. We thus tested whether urinary calcium, phosphate and citrate excretion were different between genotypes and found no obvious difference at any of the time points tested (Tables 1 - 3).

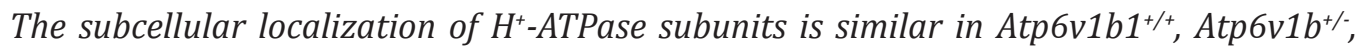
and Atp $6 \mathrm{v} 1 \mathrm{~b}^{-/}$mice

We performed immunostainings for the B1, B2 and a4 subunits of the V-type $\mathrm{H}^{+}$-ATPase (Fig. 3). In order to examine only $\mathrm{H}^{+}$-ATPase complexes in acid-secretory type A intercalated cells, we costained for the anion exchanger 1 (AE1) which is specifically expressed in type A intercalated cells [13]. As expected, the B1 subunit was not detected in kidneys from Atp $6 v 1 b 1 \%$ mice but its expression and localization was preserved in kidneys from 


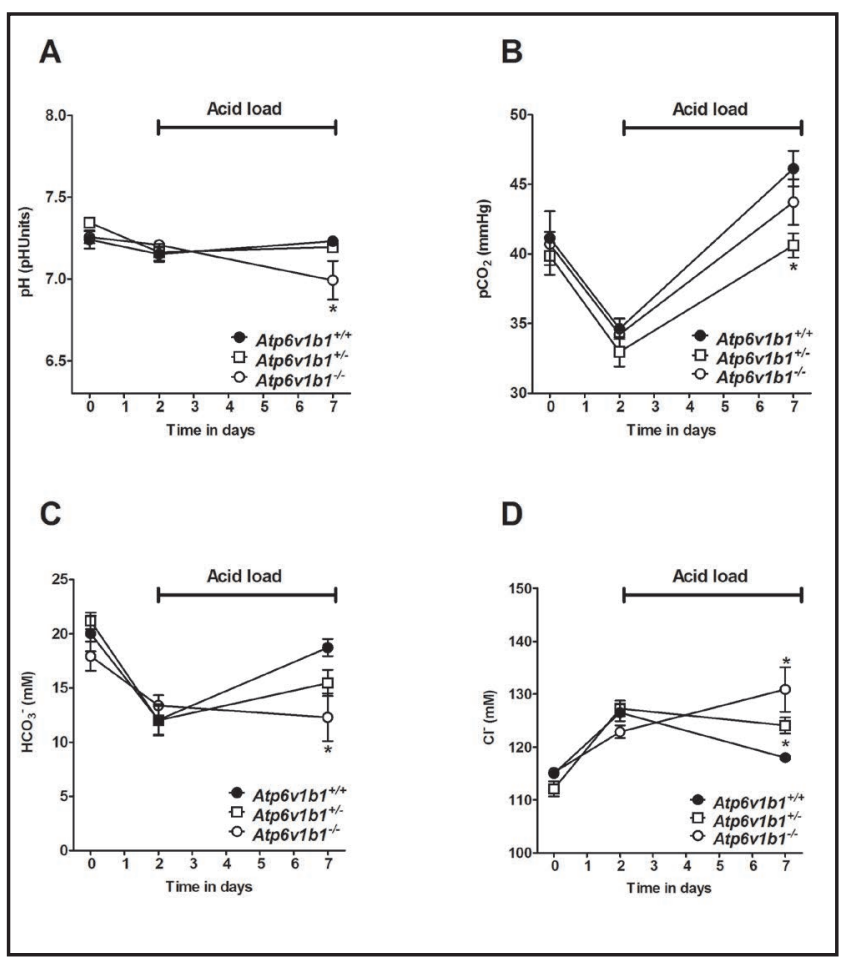

Fig. 1. Systemic acid-base parameters in Atp6v1b1 littermate mice during an $\mathrm{HCl}$ load. Blood parameters were measured in

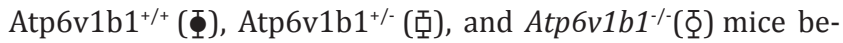
fore and during a 7 day $\mathrm{HCl}$ load (shaded area). A) Blood $\mathrm{pH}$, $B$ ) blood $\mathrm{pCO}_{2}, C$ ) blood bicarbonate and D), blood $\mathrm{Cl}^{*}$ * $\mathrm{p} \leq 0.05$

Atp $6 v 1 b 1^{+/}$mice. The apparent localization of B2 and a $4 \mathrm{H}^{+}$-ATPase subunits at the apical pole of type A intercalated cells was similar in all genotypes.

Expression of $\mathrm{H}^{+}$-ATPase subunits from the $V_{0}$ and $V_{1}$ domains is reduced in Atp $6 v 1 b 1^{+/-}$kidneys

Immunoblots on proteins enriched for apical membranes and on total membrane proteins isolated from kidneys of 7 day acid-loaded Atp $6 v 1 b 1^{+/+}$, Atp $6 v 1 \mathrm{~b} 1^{+/}$, and Atp $6 v 1 \mathrm{~b} 1^{\%}$ mice were performed assessing the abundance of the B1, B2, a4 and $\mathrm{A} \mathrm{H}^{+}$ATPase subunits belonging to the $V_{1}$ and $V_{0}$ domains (Fig. 4 and 5). B1 protein which is mostly expressed in intercalated cells of collecting duct could be detected in apical membranes from Atp $6 \mathrm{v} 1 \mathrm{b1^{+/+ }}$ and Atp $6 \mathrm{v} 1 \mathrm{b1^{+/ }}$ and was completely absent from the kidney tissue of Atp $6 v 1 \mathrm{~b} 1 \%$ (Fig. 4A and 5A). However, the relative abundance was unchanged in apical membranes from Atp $6 v 1 b 1^{+/+}$and Atp $6 v 1 b 1^{+/}$(Fig. 4A) whereas it was clearly reduced in total membranes from Atp $6 v 1 b 1^{+/}$as compared to Atp $6 v 1 b 1^{+/+}$(Fig. 5A) suggesting redistribution to the apical membrane in heterozygous animals. In contrast, the relative abundance of the B2, A and a4 $\mathrm{H}^{+}$-ATPase subunits in the apical membrane preparation was similar in

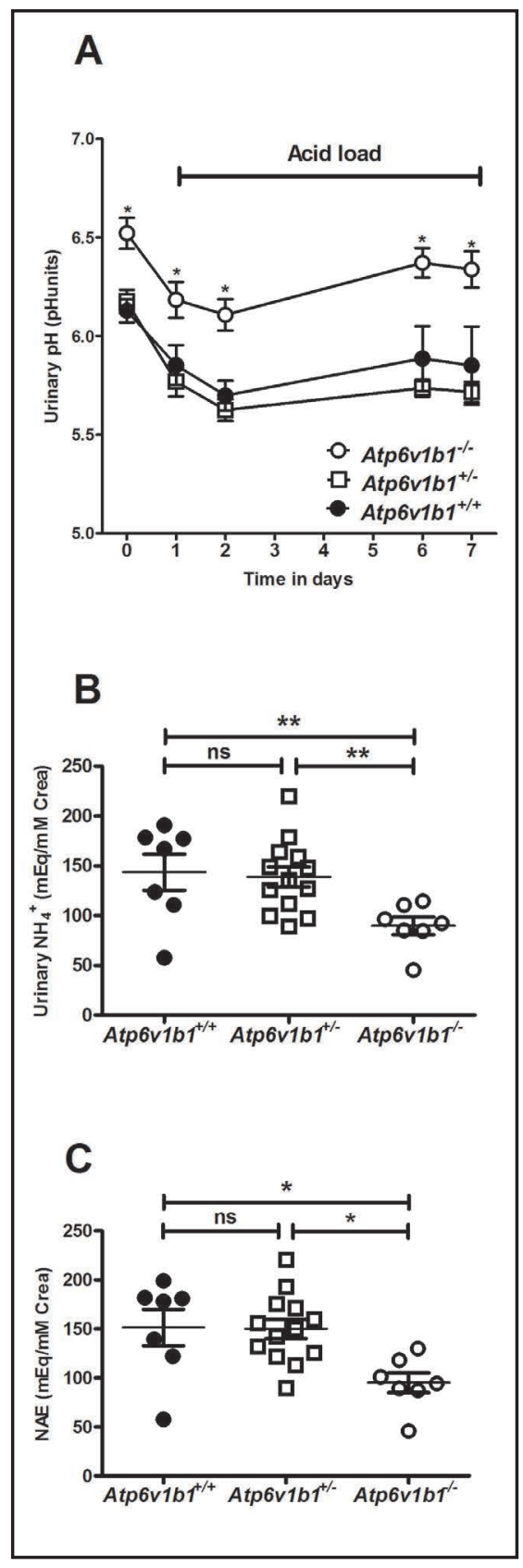

Fig. 2. Urinary $\mathrm{pH}$, ammonia, and net acid excretion in Atp6v1b1 littermate

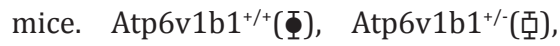
and Atp $6 v 1 b 1^{-/}$( $\left.\$\right)$ mice were observed in metabolic cages under basal conditions and during $\mathrm{HCl}$ acid loading for 7 days (shaded area). A) Urinary $\mathrm{pH}, \mathrm{B}$ ) Urinary $\mathrm{NH}_{4}{ }^{+}$normalized to urinary creatinine at day 7 of the $\mathrm{HCl}$ challenge, $\mathrm{C}$ ) Net acid excretion (NAE) after 7 days $\mathrm{HCl}$ loading. ${ }^{*} \mathrm{p} \leq 0.05,{ }^{* *} \mathrm{p} \leq 0.1$ 


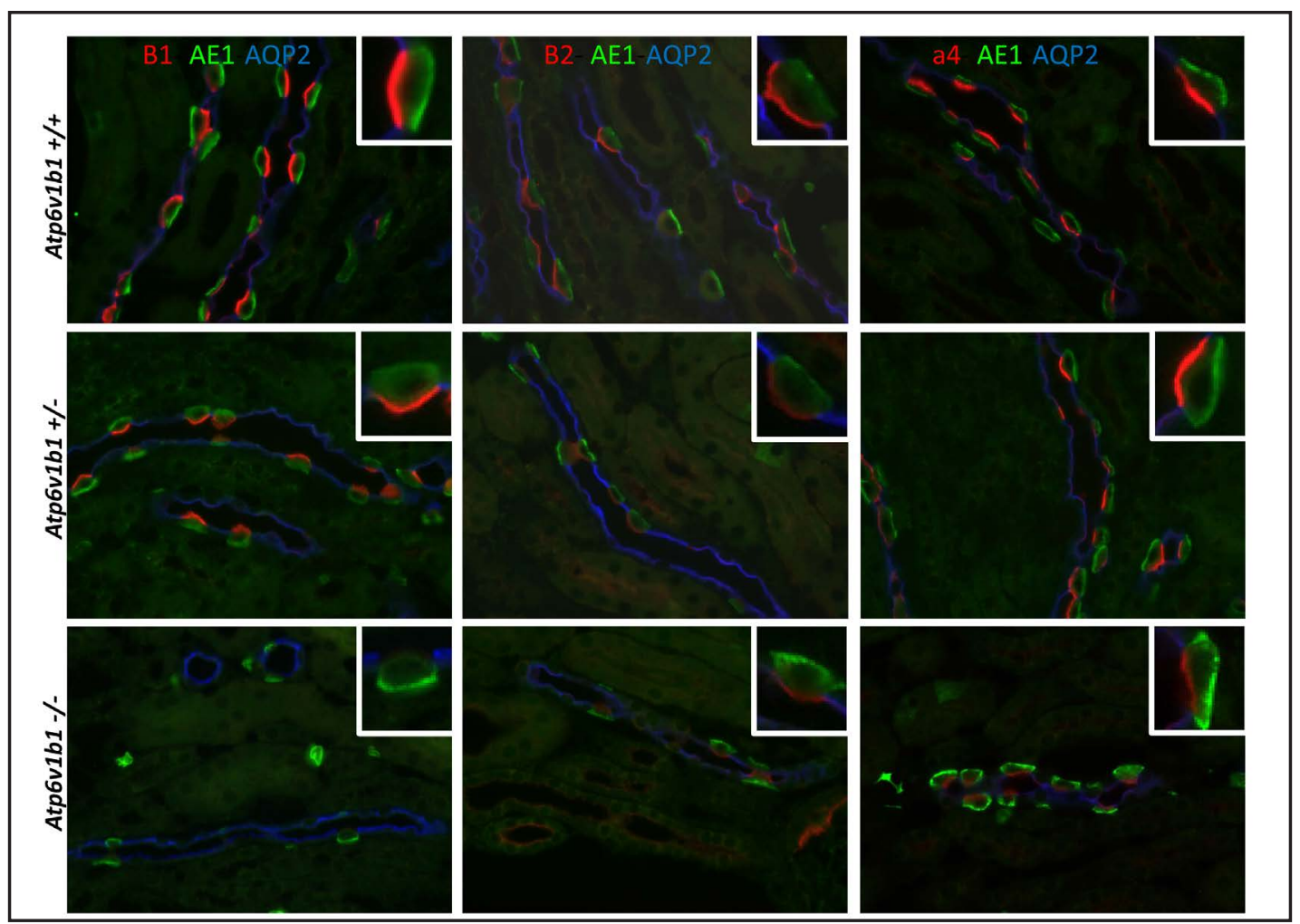

Fig. 3. Subcellular localization of $\mathrm{H}^{+}$-ATPases in type A-intercalated cells is similar in Atp $6 \mathrm{v} 1 \mathrm{~b} 1^{+/+}$, Atp $6 \mathrm{v} 1 \mathrm{b1} 1^{+/}$, and Atp $6 v 1 b 1^{\%}$ mice. Kidney sections from Atp $6 v 1 b 1^{+/+}$, Atp $6 v 1 b 1^{+/}$, and Atp $6 v 1 b 1^{\%}$ for 7 days were stained for the B1, B2 and a4 $\mathrm{H}^{+}$-ATPase subunits (in red), the anion exchanger AE1 (green) as a marker for type A intercalated cells, and for the water channel AQP2 (blue) as a marker for principal cells. Original magnification $400 \mathrm{x}$, inserts show higher magnification of single intercalated cells.

Fig. 4. Protein abundance of the B1, B2, a4 and $\mathrm{A} \mathrm{H}^{+}$-ATPase subunits in apical kidney membranes from acid-loaded Atp $6 v 1 b 1^{+/+}$, Atp $6 v 1 b 1^{+/}$, and Atp $6 v 1 b 1^{\%}$ mice. Proteins enriched from apical membranes were isolated from kidneys of Atp $6 v 1 b 1^{+/+}$(black), Atp $6 v 1 b 1^{+/-}$(grey), and Atp $6 v 1 b 1^{-/}$ (white) acid-loaded for 7 days. All immunoblot membranes were probed for $\beta$-actin to control for loading. Bar graphs summarize the ratio of specific $\mathrm{H}^{+}$-ATPase subunits over $\beta$-actin. A) B1 $\mathrm{H}^{+}$-ATPase subunit, B), B2 $\mathrm{H}^{+}$-ATPase subunit, C) a4 $\mathrm{H}^{+}$-ATPase subunit, and D) A $\mathrm{H}^{+}$-ATPase subunit. Values are mean \pm SEM ( $\mathrm{n}=5$ or 6 mice), ${ }^{* * *} \mathrm{p}$ $\leq 0.001$.
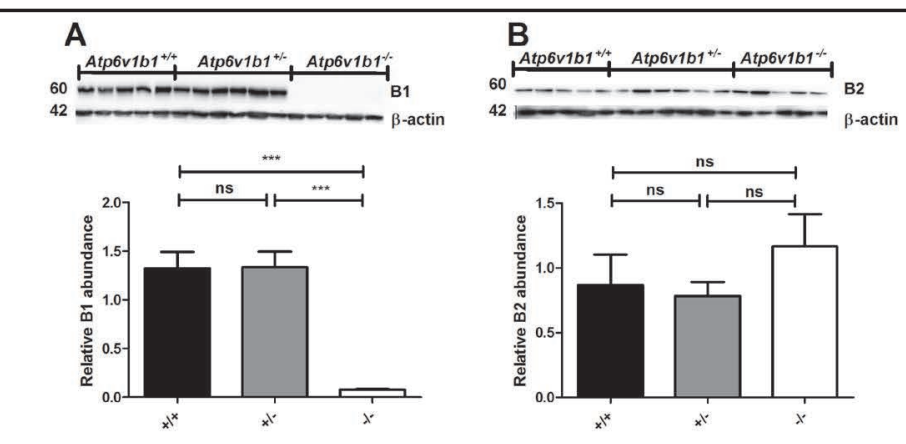

C

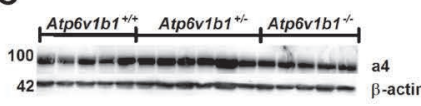

D
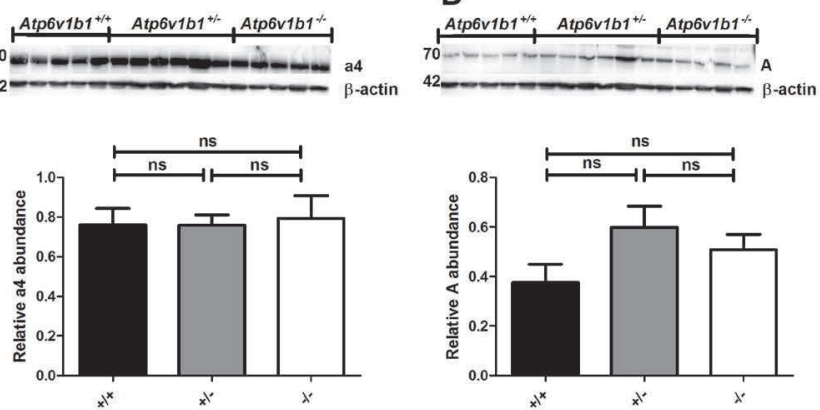


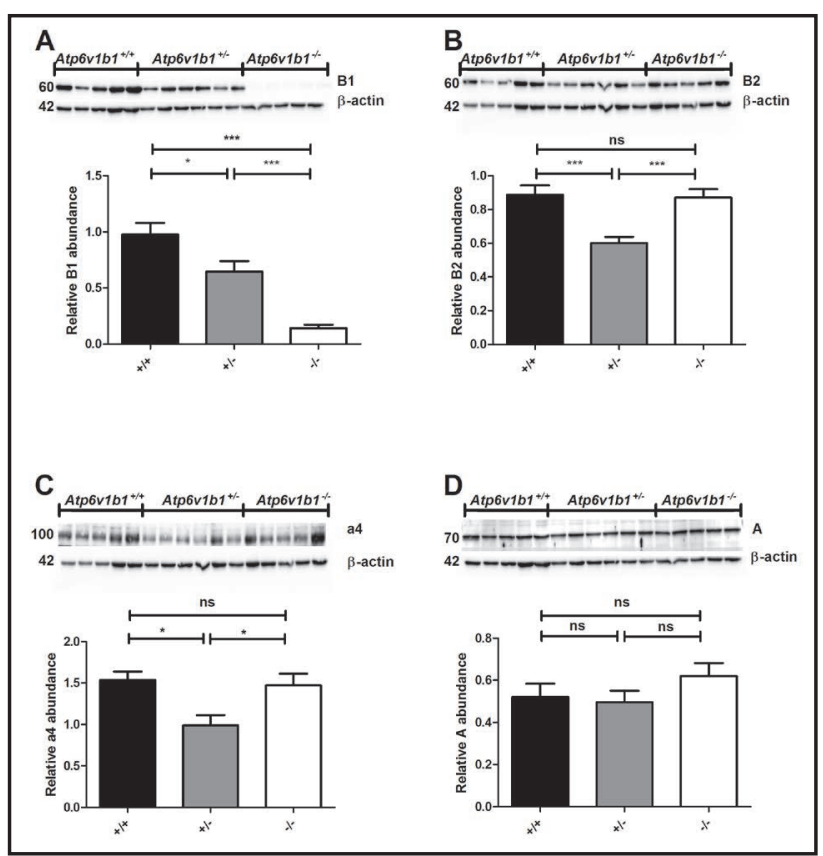

Fig. 5. Expression of the B1, B2, a 4 and $\mathrm{A} \mathrm{H}^{+}$-ATPase subunits in total kidney membrane fractions from acid-loaded $A t$ p $6 v 1 b 1^{+/+}$, Atp $6 v 1 b 1^{+/}$, and Atp $6 v 1 b 1^{\%}$ mice. Total membrane proteins were isolated from kidneys of Atp $6 v 1 b 1^{+/+}$(black), Atp $6 v 1 b 1^{+/}$(grey), and Atp $6 v 1 b 1^{\%}$ (white) acid-loaded for 7 days. All immunoblot membranes were probed for $\beta$-actin to control for loading. Bar graphs summarize the ratio of specific $\mathrm{H}+$-ATPase subunits over $\beta$-actin. A) B1 $\mathrm{H}^{+}$-ATPase subunit, B), B2 $\mathrm{H}^{+}$-ATPase subunit, C) a4 $\mathrm{H}^{+}$-ATPase subunit, and D) A $\mathrm{H}^{+}$-ATPase subunit. Values are mean \pm SEM ( $\mathrm{n}=5$ or 6 mice), * $\mathrm{p} \leq 0.05,{ }^{* * *} \mathrm{p} \leq 0.001$.

all three genotypes (Fig. 4B-D). In total membrane preparations, reduced abundance of the $\mathrm{B} 2$ and $\mathrm{a} 4$ $\mathrm{H}^{+}$-ATPase subunits in Atp $6 \mathrm{v} 1 b 1^{+/-}$kidneys were observed (Fig. 5B-D). Interestingly, in Atp $6 \mathrm{v} 1 \mathrm{~b} 1 \%$ kidneys no difference in the abundance of these subunits was detected.

Compensatory mechanisms involved in acid handling by the kidney

To assess whether compensatory mechanisms in the kidney could explain the very mild defect in Atp $6 v 1 b 1^{+/}$mice during the acid challenge, we performed immunoblots for some key proteins involved in ammonia and bicarbonate transport in the proximal tubule, thick ascending limb, and the distal nephron (late distal tubule, connecting tubule and collecting duct). No obvious regulation was detected for the sodium-proton exchanger isoform 3 (NHE3) and the electrogenic sodiumbicarbonate cotransporter NBCe1, both involved in proximal tubular bicarbonate reasbsorption. Also, the $\mathrm{Na}^{+} / \mathrm{K}^{+} / 2 \mathrm{Cl}^{-}$-cotransporter $\mathrm{NKCC} 2$,

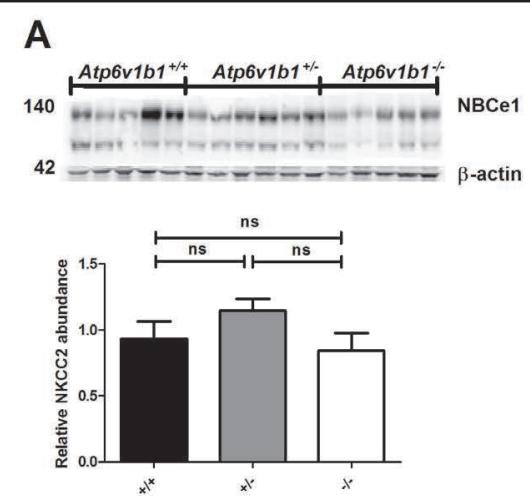

B
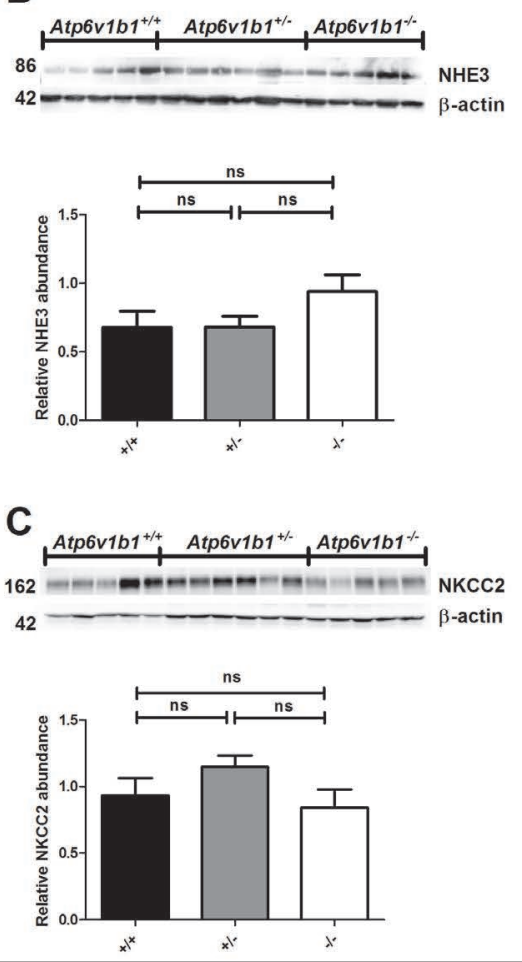

Fig. 6. Protein abundance of NBCe1, NHE3 and NKCC2 in total kidney membrane fractions from acid-loaded Atp $6 v 1 b 1^{+/+}$, Atp $6 v 1 b 1^{+/}$, and Atp $6 v 1 b 1^{-/}$mice. Total membrane proteins were isolated from kidneys

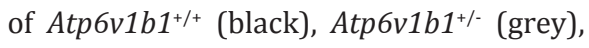
and Atp $6 \mathrm{v} 1 \mathrm{~b} 1^{\%}$ (white) acid-loaded for 7 days. All immunoblot membranes were probed for $\beta$-actin to control for loading. Bar graphs summarize the ratio of specific proteins over $\beta$-actin. A) NBCe1, B) NHE3, and $\mathrm{C}$ ) NKCC2. Values are mean \pm SEM (n= 5 or 6 mice). 
Fig. 7. Expression of AE1, pendrin and AQP2 in total kidney membrane fractions from acid-loaded

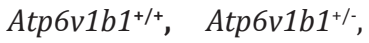
and Atp $6 v 1 b 1 \%$ mice. Total membrane proteins were isolated from kidneys of Atp $6 \mathrm{v} 1 \mathrm{b1}^{+/+}$(black), Atp6v1 $11^{+/-}$(grey), and Atp6v1b1\% (white) acidloaded for 7 days. All immunoblot membranes were probed for $\beta$-actin to control for loading. Bar graphs summarize the ratio of specific proteins over $\beta$-actin. A) AE1, B), pendrin, and C) AQP2. Values are mean \pm SEM $(n=5$ or 6 mice), ${ }^{*} \mathrm{p} \leq 0.05,{ }^{* *} \mathrm{p}$ $\leq 0.01$.
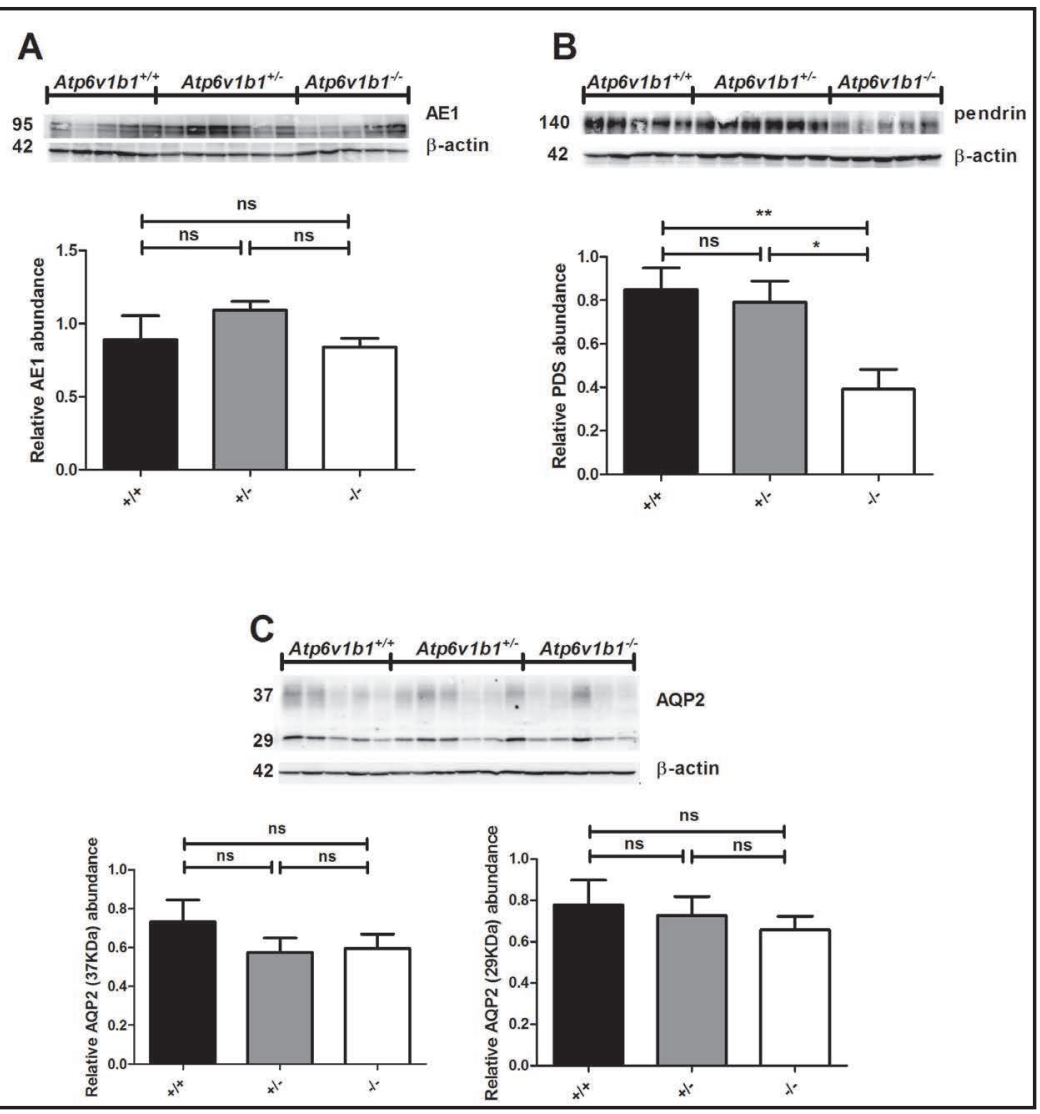

involved in renal ammonium handling, was unaltered (Fig. 6). The abundance of the type A intercalated specific anion exchanger as well as the expression of the AQP2 water channel was not different between genotypes (Fig. 7A and C). In contrast, the expression of the type $B$ intercalated cell specific anion exchanger pendrin, involved in bicarbonate secretion into urine, was strongly downregulated in kidneys from Atp $6 v 1 \mathrm{~b} 1 \%$ mice but unaltered in kidneys from Atp6v1b1+- mice (Fig. 7B).

\section{Discussion}

Loss of the $\mathrm{B} 1$ or a $4 \mathrm{H}^{+}$-ATPase subunits in human causes congenital autosomal recessive dRTA with sensorineural deafness [6, 9, 12, 14-16]. Similarly, ablation of the Atp $6 v 1 b 1$ or Atp6v0a4 genes in mice causes dRTA [17-20]. In both species, the absence of functional B1 or a $\mathrm{H}^{+}$-ATPase subunits can be associated with the development of nephrocalcinosis or -lithiasis $[6,9,12,14,16,17,21]$. Moreover, recent studies described that monoallelic mutations in these 2 genes can also lead to urinary acidification defects with elevated risk for nephrocalcinosis or-lithiasis $[10,11,22]$. Along this line, a recent study investigated the ability of Atp6v0a4 heterozygous mice regarding to handle a chronic acid load. The authors showed that these mice were totally normal when not challenged but developed an incomplete dRTA with alkaline urine during a chronic $\mathrm{NH}_{4} \mathrm{Cl}$ load and exhibited a decrease in their bone mineralo-densitometry [17]. Whether heterozygous Atp6v1b1 mice had a similar problem to respond to a chronic acid load had remained unknown. Thus, our aims were to determine whether the heterozygous Atp6v1b1 mice would exhibit an acid handling deficit and study possible compensatory mechanisms to haploinsufficiency. 


\section{Cellular Physiology Cell Physiol Biochem 2018;47:1095-1107 \begin{tabular}{c|c|c|} 
DOI: 10.1159/000490186 & O 2018 The Author(s). Published by S. Karger AG, Basel \\
www.karger.com/cpb
\end{tabular}

Haploinsufficiency in the mouse Atp6v1b1 gene leads to a mild acid-base disturbance

In contrast to Atp $6 v 1 b 1^{-/}$mice which have more alkaline urine already at baseline and develop an overt severe metabolic acidosis during the acid challenge, Atp $1 \mathrm{~b} 1^{+/}$mice had no apparent defect at baseline and exhibited only a very mild deficit in acid handling during the $\mathrm{HCl}$ load. Indeed, at the end of the treatment, Atp $6 \mathrm{v} 1 \mathrm{b1} 1^{+/-}$mice had nearly similar net acid excretion rates than Atp $6 v 1 b 1^{+/+}$mice. However, at the same time blood chloride levels was significantly higher than in $A t p 1 b 1^{+/+}$mice and blood $\mathrm{pCO}_{2}$ was lower. Since the measurement of blood gas status in mice is technically challenging, blood chloride levels are likely the most stable parameter indicating a mild metabolic acidosis in heterozygous mice. This increase in blood $\mathrm{Cl}^{-}$concentration both in heterozygous and $\mathrm{KO}$ mice cannot be linked to dehydration as hematocrit levels were not different between the three strains of mice. Moreover, the calculated sodium-chloride difference, an index for metabolic acidosis versus dehydration [23] showed a significant lower value in KO mice compared to WT mice at the end of the acid load and an intermediate but not significant value for heterozygous animals. Once again, this may indicate an acid-base disturbance.Finally, the low $\mathrm{pCO}_{2}$ may point to a partial respiratory compensation. This very mild phenotype has also been observed in humans with heterozygous mutations in the $\mathrm{B} 1$ or a4 $\mathrm{H}^{+}$-ATPase subunits $[10,22]$ as well as in Atp6v0a4+/ mice [17]. While Atp6v0a4\% mice develop severe spontaneous metabolic acidosis with high mortality before weaning, Atp $6 \mathrm{v} 0 \mathrm{a}^{+/}$mice exhibit no phenotype under control diet. However, Atp $6 \mathrm{v} 0 \mathrm{a}^{+/-}$mice developed acidosis during a prolonged chronic acid load (at least 2 weeks of treatment). Here, we performed only 7 days of $\mathrm{HCl}$ load which may explain why we could not detect a more pronounced deficit in acid handling.

Contrary to the phenotype of human heterozygous ATP6V1B1 mutation carriers [10, $11]$, we were not able to detect any abnormality in urinary citrate or calcium excretion in Atp6v1b1+/- mice.

\section{Haploinsufficiency and dRTA}

An increasing number of human case reports as well as studies in rodent models suggests that an incomplete from of dRTA can be associated to or caused by monoallelic mutations or haploinsufficiency of the ATP6V1B1 and ATP6V0A4 genes $[10,11,17,18,22]$. Similarly, hapoloinsufficiency of the Rhcg ammonia channel can also cause a mild form of dRTA in rodents [24]. However, the mechanisms causing dRTA may be different in patients with monoallelic mutations and in rodents with deletion of one allele. The major difference may be that the mutated B1 or a4 protein may even assemble into the whole pump complex and then impair its proper function. Since pumps contain 3 copies of the B1 protein and one copy of the a 4 protein, particularly in the case of B1 mutations, integration of one, two or even three defective copies into the pump may be possible with varying degrees of impairment. Indeed, defective pump activity has been shown for many B1 mutations including some found in patients with incomplete dRTA and only monoallelic mutations [10, 11, 25]. In contrast, the incomplete dRTA seen in heterozygous Atp6v0a4 mice or in our Atp6v1b1 model may result from a gene dosage effect where less functional pumps can be formed due to reduced availability of a 4 or B1 subunits. In our mouse model, a reduced abundance of the B1 protein was detected in heterozygous mice whereas no evidence was detected that trafficking of pumps to the apical pole of type A intercalated cells was severely impaired.

\section{Renal adaptation to the reduced $B 1$ protein expression}

Immunoblotting showed that the reduced availability of B1 subunits at the luminal membrane in the Atp $6 \mathrm{v} 1 \mathrm{b1} 1^{+/}$mice was associated also with a reduction in the a4 and B2 subunits. Reduced abundance of B2 is surprising as we have shown previously that B2 partly compensates for the loss of B1 in homozygous Atp6v1b1 KO mice [26]. However, no difference in total B2 protein had been detectable but a clear shift of B2 protein from an intracellular compartment to the luminal membrane [26]. More recently, the B1 KO mouse model was crossed with a mouse model expressing EGFP in intercalated cells allowing to purify them and to assess the expression of the various subunits on a purified population 


\section{Cellular Physiology Cell Physiol Biochem 2018;47:1095-1107

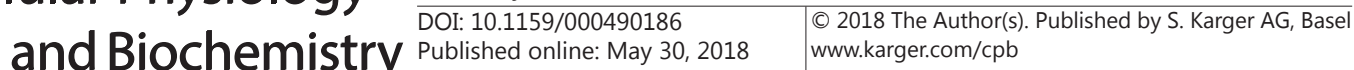 \\ Bourgeois et al.: Phenotype of Atp6v1b1 Haploinsufficiency in Mice}

of collecting duct intercalated cells [27]. The up-regulation of the B2 subunit was confirmed but also a downregulation of the A, E1, $\mathrm{H}$ and a4 subunits were documented. This finding is in accordance with the overall reduction in $\mathrm{H}^{+}$-ATPase activity in the Atp $6 v 1 b 1 \%$ mice $[19,20$, $26,28]$. Thus, the mechanism how haploinsufficiency of the B1 protein can cause reduced a4 and $\mathrm{B} 2$ protein expression remains unclear.

We further examined whether compensatory mechanisms in the transport of $\mathrm{NH}_{4}^{+}$and $\mathrm{HCO}_{3}^{-}$in the proximal nephron and the collecting duct intercalated cells would contribute to the observed mild phenotype in Atp $6 v 1 b 1^{+\%}$. We could not detect any change in the mechanisms located in the proximal nephron but found a 2 -fold decrease in the expression of pendrin in Atp $6 \mathrm{v} 1 \mathrm{~b} 1^{-/}$kidneys. Reduction of pendrin expression has already been described in a mouse model of Atp6v0a4\% [18]. The authors had explained this down-regulation by the fact that excretion of $\mathrm{HCO}_{3}^{-}$by the pendrin exchanger would be counterproductive in the presence of metabolic acidosis. Indeed, metabolic acidosis triggers downregulation of pendrin also in normal mice $[29,30]$ and the downregulation of pendrin in Atp $6 v 1 \mathrm{~b} 1 \%$ mice may also prevent a further aggravation of metabolic acidosis.

Taken together, we show that haploinsufficiency in Atp6v1b1 mice led to a mild defect in renal acid excretion. Reduced expression of the $\mathrm{B} 1 \mathrm{H}^{+}$-ATPase subunit causes downregulation of the B2, and a4 $\mathrm{H}^{+}$-ATPase subunits. This phenotype is in agreement with the mild deficit in acid handling which was observed in human studies with patients heterozygous of ATP6V1B1 mutations and may provide some explanations for the disease mechanism.

\section{Acknowledgements}

We thank Pascal Houillier for kind support in titratable acidity determination, Nadine Nägele for her excellent technical expertise in the UniCel DxC 800 Synchron Clinical Systems and the ZIRP Core facility for support. This work was supported by a grant from the Swiss National Science Foundation (31003A_155959) to CAW.

\section{Disclosure Statement}

The authors declare to have no competing interests.

\section{References}

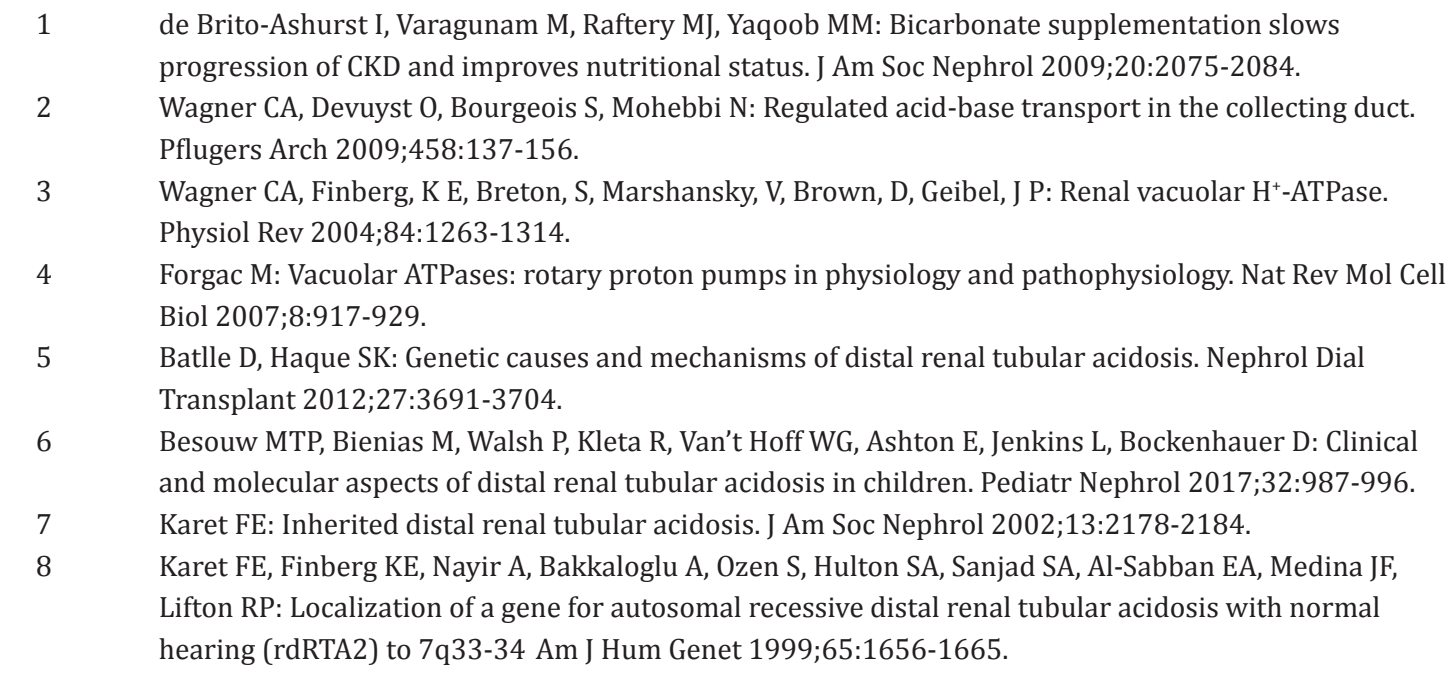




\section{Cellular Physiology Cell Physiol Biochem 2018;47:1095-1107

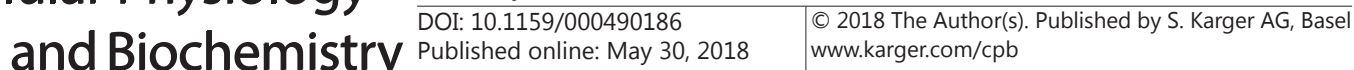

Bourgeois et al.: Phenotype of Atp6v1b1 Haploinsufficiency in Mice

Karet FE, Finberg KE, Nelson RD, Nayir A, Mocan H, Sanjad SA, Rodriguez-Soriano J, Santos F, Cremers CW, Di Pietro A, Hoffbrand BI, Winiarski J, Bakkaloglu A, Ozen S, Dusunsel R, Goodyer P, Hulton SA, Wu DK, Skvorak AB, Morton CC, Cunningham MJ, Jha V, Lifton RP: Mutations in the gene encoding B1 subunit of H+-ATPase cause renal tubular acidosis with sensorineural deafness. Nat Genet 1999;21:8490.

Zhang J, Fuster DG, Cameron MA, Quinones H, Griffith C, Xie XS, Moe OW: Incomplete distal renal tubular acidosis from a heterozygous mutation of the V-ATPase B1 subunit. Am J Physiol Renal Physiol 2014;307:F1063-1071.

Dhayat NA, Schaller A, Albano G, Poindexter J, Griffith C, Pasch A, Gallati S, Vogt B, Moe OW, Fuster DG: The Vacuolar H+-ATPase B1 Subunit Polymorphism p.E161K Associates with Impaired Urinary Acidification in Recurrent Stone Formers. J Am Soc Nephrol 2016;27:1544-1554.

12 Mohebbi N, Vargas-Poussou R, Hegemann SC, Schuknecht B, Kistler AD, Wuthrich RP, Wagner CA: Homozygous and compound heterozygous mutations in the ATP6V1B1 gene in patients with renal tubular acidosis and sensorineural hearing loss. Clin Genet 2013;83:274-278.

13 Alper SL, Natale J, Gluck S, Lodish HF, Brown D: Subtypes of intercalated cells in rat kidney collecting duct defined by antibodies against erythroid band 3 and renal vacuolar $\mathrm{H}^{+}$-ATPase. Proc Natl Acad Sci U S A 1989;86:5429-5433.

14 Smith AN, Skaug, J, Choate, K A, Nayir, A, Bakkaloglu, A, Ozen, S, Hulton, S A, Sanjad, S A, Al-Sabban, E A, Lifton, R P, Scherer, S W, Karet, F E: Mutations in ATP6N1B, encoding a new kidney vacuolar proton pump 116-kD subunit, cause recessive distal renal tubular acidosis with preserved hearing. Nat Genet 2000;26:71-75.

15 Stover EH, Borthwick, K J, Bavalia, C, Eady, N, Fritz, D M, Rungroj, N, Giersch, A B, Morton, C C, Axon, P R, Akil, I, Al-Sabban, E A, Baguley, D M, Bianca, S, Bakkaloglu, A, Bircan, Z, Chauveau, D, Clermont, M J, Guala, A, Hulton, S A, Kroes, H, Li, Volti, G, Mir, S, Mocan, H, Nayir, A, Ozen, S, Rodriguez Soriano, J, Sanjad, S A, Tasic, V, Taylor, C M, Topaloglu, R, Smith, A N, Karet, F E: Novel ATP6V1B1 and ATP6V0A4 mutations in autosomal recessive distal renal tubular acidosis with new evidence for hearing loss. J Med Genet 2002;39:796-803.

V16 Vargas-Poussou R, Houillier P, Le Pottier N, Strompf L, Loirat C, Baudouin V, Macher MA, Dechaux M, Ulinski T, Nobili F, Eckart P, Novo R, Cailliez M, Salomon R, Nivet H, Cochat P, Tack I, Fargeot A, Bouissou F, Kesler GR, Lorotte S, Godefroid N, Layet V, Morin G, Jeunemaitre X, Blanchard A: Genetic investigation of autosomal recessive distal renal tubular acidosis: evidence for early sensorineural hearing loss associated with mutations in the ATP6V0A4 gene. J Am Soc Nephrol 2006;17:1437-1443.

17 Norgett EE, Golder ZJ, Lorente-Canovas B, Ingham N, Steel KP, Karet Frankl FE: Atp6v0a4 knockout mouse is a model of distal renal tubular acidosis with hearing loss, with additional extrarenal phenotype. Proc Natl Acad Sci U S A 2012;109:13775-13780.

-18 Hennings JC, Picard N, Huebner AK, Stauber T, Maier H, Brown D, Jentsch TJ, Vargas-Poussou R, Eladari D, Hubner CA: A mouse model for distal renal tubular acidosis reveals a previously unrecognized role of the V-ATPase a4 subunit in the proximal tubule. EMBO Mol Med 2012;4:1057-1071.

19 Finberg KE, Wagner CA, Bailey MA, Paunescu TG, Breton S, Brown D, Giebisch G, Geibel JP, Lifton RP: The B1-subunit of the $\mathrm{H}(+)$ ATPase is required for maximal urinary acidification. Proc Natl Acad Sci U S A 2005;102:13616-13621.

-20 Rothenberger F, Velic A, Stehberger PA, Kovacikova J, Wagner CA: Angiotensin II stimulates vacuolar $\mathrm{H}^{+}$-ATPase activity in renal acid-secretory intercalated cells from the outer medullary collecting duct. J Am Soc Nephrol 2007;18: 2085-2093.

21 Renkema KY, Velic A, Dijkman HB, Verkaart S, van der Kemp AW, Nowik M, Timmermans K, Doucet A, Wagner CA, Bindels RJ, Hoenderop JG: The calcium-sensing receptor promotes urinary acidification to prevent nephrolithiasis. J Am Soc Nephrol 2009;20:1705-1713.

22 Imai E, Kaneko S, Mori T, Okado T, Uchida S, Tsukamoto Y: A novel heterozygous mutation in the ATP6V0A4 gene encoding the V-ATPase a4 subunit in an adult patient with incomplete distal renal tubular acidosis. Clin Kidney J 2016;9:424-428.

-23 Mallat J, Barrailler S, Lemyze M, Pepy F, Gasan G, Tronchon L, Thevenin D: Use of sodium-chloride difference and corrected anion gap as surrogates of Stewart variables in critically ill patients. PLoS One 2013;8:e56635. 


\section{Cellular Physiology Cell Physiol Biochem 2018;47:1095-1107 \begin{tabular}{l|l} 
DOI: 10.1159/000490186 \\
and Biochemistry Published online: May 30, 2018 & $\begin{array}{l}\text { O } 2018 \text { The Author(s). Published by S. Karger AG, Basel } \\
\text { www.karger.com/cpb }\end{array}$ \\
\cline { 2 - 3 } & Bourt
\end{tabular} \\ Bourgeois et al.: Phenotype of Atp6v1b1 Haploinsufficiency in Mice}

24 Bourgeois S, Bounoure L, Christensen EI, Ramakrishnan SK, Houillier P, Devuyst O, Wagner CA: Haploinsufficiency of the ammonia transporter Rhcg predisposes to chronic acidosis: Rhcg is critical for apical and basolateral ammonia transport in the mouse collecting duct. J Biol Chem 2013;288:55185529.

25 Fuster DG, Zhang J, Xie XS, Moe OW: The vacuolar-ATPase B1 subunit in distal tubular acidosis: novel mutations and mechanisms for dysfunction. Kidney Int 2008;73:1151-1158.

-26 Paunescu TG, Russo LM, Da Silva N, Kovacikova J, Mohebbi N, Van Hoek AN, McKee M, Wagner CA, Breton S, Brown D: Compensatory membrane expression of the V-ATPase B2 subunit isoform in renal medullary intercalated cells of B1-deficient mice. Am J Physiol Renal Physiol 2007;293:F1915-1926. Vedovelli L, Rothermel JT, Finberg KE, Wagner CA, Azroyan A, Hill E, Breton S, Brown D, Paunescu TG: Altered V-ATPase expression in renal intercalated cells isolated from B1 subunit-deficient mice by fluorescence-activated cell sorting. Am J Physiol Renal Physiol 2013;304:F522-532.

Bourgeois S, Bounoure L, Mouro-Chanteloup I, Colin Y, Brown D, Wagner CA: The ammonia transporter RhCG modulates urinary acidification by interacting with the vacuolar proton-ATPases in renal intercalated cells. Kidney Int 2017;10.1016/j.kint.2017.07.027DOI:10.1016/j.kint.2017.07.027 Hafner P, Grimaldi R, Capuano P, Capasso G, Wagner CA: Pendrin in the mouse kidney is primarily regulated by $\mathrm{Cl}$ - excretion but also by systemic metabolic acidosis. Am J Physiol Cell Physiol 2008;295:C1658-1667.

Mohebbi N, Perna A, van der Wijst J, Becker HM, Capasso G, Wagner CA: Regulation of two renal chloride transporters, AE1 and pendrin, by electrolytes and aldosterone. PLoS One 2013;8:e55286. Jorgensen K: Titrimetric determination of the net excretion of acid/base in urine. Scand J Clin Lab Invest 1957;9:287-291. Siggaard-Andersen O: Titratable acid or base of body fluids. Ann N Y Acad Sci 1966;133:41-58. Stehberger PA, Shmukler BE, Stuart-Tilley AK, Peters LL, Alper SL, Wagner CA: Distal renal tubular acidosis in mice lacking the AE1 (band3) Cl-/HCO3- exchanger (slc4a1). J Am Soc Nephrol 2007;18:1408-1418.

-34 Wagner CA, Lukewille U, Valles P, Breton S, Brown D, Giebisch GH, Geibel JP: A rapid enzymatic method for the isolation of defined kidney tubule fragments from mouse. Pflugers Arch 2003;446:623-632. base transporters in rat kidney. Am J Physiol Renal Physiol 2007;293:F416-427. Lowry OH, Rosebrough NJ, Farr AL, Randall RJ: Protein measurement with the Folin phenol reagent. J Biol Chem 1951;193:265-275. Atp6v1b1, the murine vacuolar H+ -ATPase B1-subunit. Gene 2003;318:25-34. Wagner CA, Loffing-Cueni D, Yan Q, Schulz N, Fakitsas P, Carrel M, Wang T, Verrey F, Geibel JP, Giebisch G, Hebert SC, Loffing J: Mouse model of type II Bartter's syndrome. II. Altered expression of renal sodium- and water-transporting proteins. Am J Physiol Renal Physiol 2008;294:F1373-1380. 